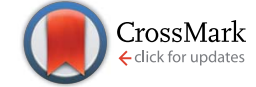

Cite this: RSC Adv., 2016, 6, 25713

Received 26th January 2016

Accepted 23rd February 2016

DOI: $10.1039 / \mathrm{c} 6 \mathrm{ra0} 2365 \mathrm{~g}$

www.rsc.org/advances

\section{A base promoted multigram synthesis of aminoisoxazoles: valuable building blocks for drug discovery and peptidomimetics $\uparrow$}

\author{
Bohdan A. Chalyk, ${ }^{a}$ Inna Y. Kandaurova, ${ }^{\text {b }}$ Kateryna V. Hrebeniuk, \\ Olga V. Manoilenko, ${ }^{a}$ Irene B. Kulik, ${ }^{d}$ Rustam T. Iminov, ${ }^{a}$ Vladimir Kubyshkin, ${ }^{e}$ \\ Anton V. Tverdokhlebov, ${ }^{\star a}$ Osman K. Ablialimov*a and Pavel K. Mykhailiuk ${ }^{\star a c}$
}

A practical multigram metal free synthesis of isoxazole-containing building blocks from commercially available amino acids was elaborated. The key reaction was a regioselective $[3+2]$-cycloaddition of in situ generated nitrile oxides with alkynes/enamines. The obtained building blocks were used in the preparation of bioactive compounds and peptidomimetics.

\section{Introduction}

The isoxazole core is a structural element in many commercial pharmaceuticals (Fig. 1). The range of biological activities of the isoxazole-containing drugs is broad: analgesic, ${ }^{1}$ anti-inflammatory, ${ }^{\mathbf{1 a}, \boldsymbol{c}, \mathbf{2}}$ anthelmintic, ${ }^{\mathbf{3}}$ anti-depressant, ${ }^{\mathbf{4}}$ anti-bacterial, ${ }^{\mathbf{5}}$ anticancer, ${ }^{6}$ insecticidal, ${ }^{7}$ nootropic, ${ }^{8}$ anxiolytic, ${ }^{8 a}$ neuroprotective, ${ }^{9}$ and HIV-inhibitory agents. ${ }^{10}$ In this context, the development of practical methods towards isoxazole-based building blocks from common cheap starting materials is truly desirable.

Nitrile oxides are useful intermediates towards the synthesis of a wide plethora of isoxazole-based architectures. ${ }^{11 \boldsymbol{a}-\boldsymbol{h}}$ However; most of these methods either utilize toxic metals or hypervalent iodine compounds ${ }^{\mathbf{1 1 h}}$ which in turn, are not environmentally friendly. At the same time, there are just a few known reports dealing with metal-free conditions and most common are based on the use of triethylamine $\mathrm{e}^{\mathbf{1 2 a}-\boldsymbol{b}}$ and sodium perchlorate/triethylamine. ${ }^{\mathbf{1 2 c}}$ Therefore, the development of

${ }^{a}$ Enamine Ltd., Chervonotkatska 78, 01103 Kyiv, Ukraine; Web: http://www.enamine. net. E-mail: A.tverdohlebov@mail.enamine.net; O.ablialimov@mail.enamine.net; Pavel.Mykhailiuk@gmail.com; Pavel.Mykhailiuk@mail.enamine.net

${ }^{b}$ Department of Chemistry, Kyiv Polytechnic Institute, Prosp. Peremohy 37, Kyiv 03056, Ukraine

${ }^{\circ}$ Department of Chemistry, Taras Shevchenko National University of Kyiv, Volodymyrska Street 64, Kyiv 01601, Ukraine

${ }^{d}$ Institute of Bioorganic Chemistry \& Petrochemistry, NAS of Ukraine, Murmanska 1, Kyiv 02660, Ukraine

eInstitute of Chemistry, Technical University of Berlin, Müller-Breslau-Str. 10, Berlin 10623, Germany

$\dagger$ Electronic supplementary information (ESI) available: Experimental procedure and characterization of all new compounds (PDF). CCDC [1442715 and 1442716]. For ESI and crystallographic data in CIF or other electronic format see DOI: $10.1039 / \mathrm{c} 6 \mathrm{ra02365g}$ metal-free protocols towards the synthesis of compounds bearing isoxazole core is of particular interest. ${ }^{12 d, e}$

The use of amino acids ${ }^{\mathbf{1 3 a - h}}$ in construction of isoxazolecontaining compounds has been known before. However, these reports, dealt with the specific amino acids, and the studies have not been performed systematically on large variety of substrates. Taking into account the need of exploration of metal-free protocols as well as search for easily available substrates, herein we would like to elaborate on a general practical multigram metal-free synthesis of isoxazole-core building blocks starting from commonly available and diverse $\alpha$-, $\beta$ - and $\gamma$-amino acids.

\section{Results and discussion}

\section{Synthesis}

1. Synthesis of chloroximes from amino acids. The initial synthesis step was reduction of the amino acid carboxyl-groups in a number of N-Boc protected amino acids. Resulting N-Boc amino alcohols were subsequently oxidized into the corresponding aldehydes (Table 1). These aldehydes formed oximes upon treatment with hydroxylamine under mildly basic conditions (sodium hydrogen carbonate). The oximes were then treated with $\mathrm{N}$-chlorosuccinimide under acidic conditions to afford the target N-Boc protected chloroximes 1-7 in good yields. The products were white powders that could be stored at room temperature for at least several months as exemplified in Table 1.

2. Synthesis of N-Boc aminoisoxazoles via $[3+2]$-cycloaddition. It is worth mentioning that our methodology for the synthesis of variety isoxazoles is known and here we would just mention some selected examples where the similar conditions like base or reaction temperatures were applied. Johnson et al. reported on the regioselective synthesis of 3,4disubstituted isoxazoles between enolsilanes and nitrile 


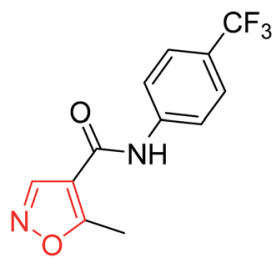

Leflunomide anti-reumatic

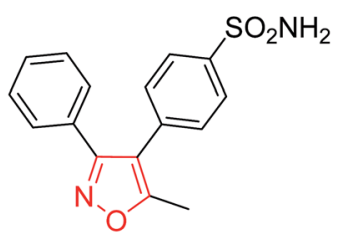

Valdecoxib anti-inflammatory

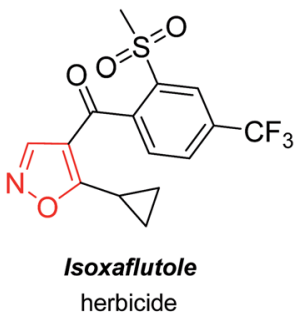

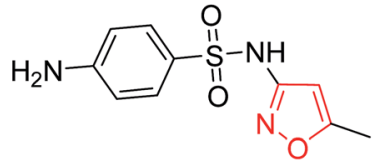

Sulfamethoxazole

antibiotic
$\mathrm{HO}$<smiles>NCc1ccno1</smiles>

Muscimol sedative

Fig. 1 Commercialized biologically active derivatives of isoxazole.

oxides. ${ }^{14}$ In the same vein, the Zhu group and later Wang and co-workers reported on the synthesis of 3,4-disubstituted isoxazoles in high yields. ${ }^{15 a, b}$ The key point of the reported protocols was the reaction of in situ generated enamines from corresponding ketones or $\beta$-keto esters and nitrile oxides. Caddick and co-workers reported and interesting strategy towards the synthesis of 3,5-disubstituted isoxazoles bearing sulfonamide group at the 5-position. ${ }^{16}$ Later the Shibata group developed the strategy for the synthesis of isoxazole triflones. ${ }^{17}$ Hamme et al. reported on the synthesis of 3,5disubstituted isoxazoles with electron withdrawing group at the 5-position by the reaction of 1,1-disubstituted bromoalkenes with nitrile oxides. ${ }^{18 a, b}$ Last but not least Schmidt and co-workers reported on the regioselective synthesis of 4-trifluorosubstituted isoxazoles in good yields. ${ }^{19}$ All the aforementioned methods avoided the usage of metalmediated reactions which prompted us to follow the similar conditions in order to synthesize a large panel of aminoisoxazoles in large scale.

In our case, synthesis of isoxazoles from the corresponding in situ generated nitrile oxides and alkynes/enamines was analogous to the mentioned above methods. Namely, treatment of chloroximes 1-7 with a mild base (sodium hydrogen carbonate or triethylamine) at either the room temperature or at $0{ }^{\circ} \mathrm{C}$ led to generation of corresponding nitrile oxides (Table 2). Subsequent addition of enamines 8-10 (1.2 eq.) to these in situ generated nitrile oxides lead to $[3+2]$-cycloaddition intermediates that readily eliminated dimethylamine to give the 3,4-disubstituted isoxazoles in a regioselective fashion as previously reported with push-pull enamines (Table 2, A).$^{20}$ In contrast, terminal alkynes 11, 12 afforded a mixture of 3,4-/3,5-isomers $\sim 30 / 70$ when reaction was performed at the room temperature. ${ }^{21}$ Nevertheless, the same reaction at $0{ }^{\circ} \mathrm{C}$ exhibited an improved regioselectivity of $\sim 10 / 90$, and the major 3,5-disubstituted isomers were easily isolated by column chromatography. ${ }^{22}$

While the above described $[3+2]$ cycloaddition reactions were performed in ethyl acetate the synthesis also worked well in tetrahydrofuran, dichloromethane, dimethoxymethane or chloroform, though with compromised regioselectivity. At the same time synthesis of isoxazoles in water as environmentally benign solvent is of high interest. ${ }^{23}$ It is also worth mentioning, that these reactions were performed under obligatory high dilution - substrate/solvent $=1 / 10(\mathrm{wt} / \mathrm{v})$ - otherwise formation of side furoxans was observed. ${ }^{24}$

As the result we obtained a variety of N-Boc aminoisoxazoles initially starting from amino acids, and the synthetic approach was scalable such that up to $50 \mathrm{~g}$ of a product (Boc-6-H) was obtained in a single synthesis run.

3. Synthesis of isoxazole-containing amines and amino acids. We also made several forays toward the cleavage of TMS-group utilizing $\mathrm{K}_{2} \mathrm{CO}_{3}$ or trifluoroacetic acid (TFA) as TMS-scavengers, ${ }^{25}$ but unfortunately in our case the described procedure was not that efficient, furnishing the desired products in moderate yields. Moreover, attempts to cleave TMS-group with $4 \mathrm{M} \mathrm{HCl}$ in dioxane were also not optimal giving low yields. Though, these forays were not successful, it allowed us to improve our tactics. As a result, we found that cleavage of the TMS-group from the isoxazole core was easily achieved by treatment with catalytic amounts of $\mathrm{KHF}_{2}$ in methanol-water mixture. Resulting 3-substituted isoxazoles were obtained in excellent yields (Table 3).

As next, cleavage of N-Boc group from all compounds was performed under acidic conditions to afford the target building blocks - aminoisoxazoles (Table 4).

Carboxymethyl-substituted isoxazoles were saponificated with sodium hydroxide in methanol to afford corresponding free amino acids in good yields (Table 5).

The structures of two final compounds were confirmed by X-ray analysis (Fig. 2). Interestingly, the structure of Boc-4ACOMe indicates a repulsion occurring between the carbamate carbonyl oxygen and the isoxazole nitrogen, similar to what has been recently reported for analogous structures with 1,3-oxa/ thiazine in place of the isoxasole. ${ }^{26}$ 
Table 1 Chloroximes synthesized starting from N-Boc amino acids

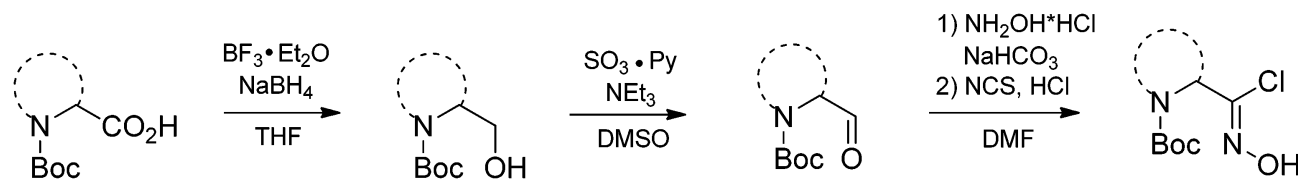

1-7

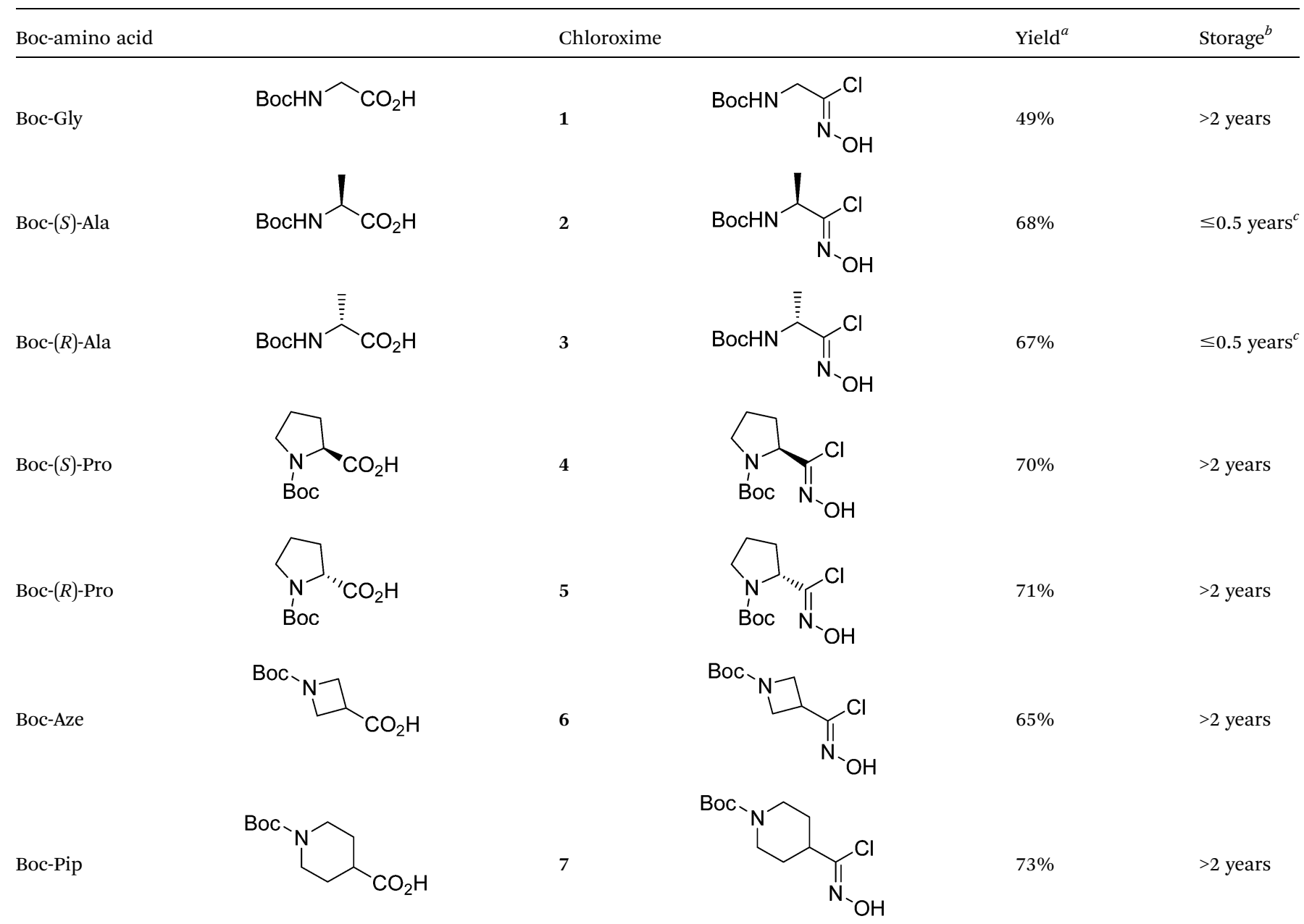

${ }^{a}$ Overall yield over four steps. ${ }^{b}$ The products were stored in closed flasks at the room temperature. ${ }^{c}$ The products were stored at $0{ }^{\circ} \mathrm{C}$ under argon. After six months $c a$. $10 \%$ decomposition was found according to ${ }^{1} \mathrm{H}$ NMR.

\section{Practical applications}

After having established a practical general synthetic protocol towards isoxazole-containing building blocks, we also aimed to demonstrate applicability of the synthesized structures in other chemical areas.

1. Synthesis of a drug candidate. ABT-418 is a known nootropic agent. ${ }^{27 a}$ Recently, chemists at Abbott Laboratories synthesized its bioisostere $\mathbf{1 6}$ in four steps and 7.3\% total yield starting from 4 and 2-bromopropene. ${ }^{27 b}$ Herein, we have developed an alternative approach to afford compound 16 (Scheme 1). First, $[3+2]$-cycloaddition between allylbromide and nitrile oxide generated from chloroxine 4 gave isoxazoline 13 in 95\% yield. Next, elimination of hydrogen bromide under basic conditions gave isoxazole 14. Cleavage of the N-Boc group produced free amine 15, which was then subjected to reductive amination with aqueous formaldehyde to afford the target product 16 in gram quantities. The overall yield of the synthesis was $55 \%$ over 5 steps.

2. Synthesis of peptidomimetics. We also envisioned that chiral aminoisoxazoles could be used to prepare conformationally restricted peptidomimetics. ${ }^{28}$ In this case the heterocyclic fragment will act as a rigid peptide bond substitute ${ }^{29}$ (Scheme 2).

In addition, isomeric oxazoles and thiazoles are common in the backbones ${ }^{30}$ of various ribosomally synthesized and posttranslationally modified peptides. ${ }^{31}$ Construction of an azole 
Table 2 The synthesis of $\mathrm{N}$-Boc aminoisoxazoles via [3+2]-cycloaddition

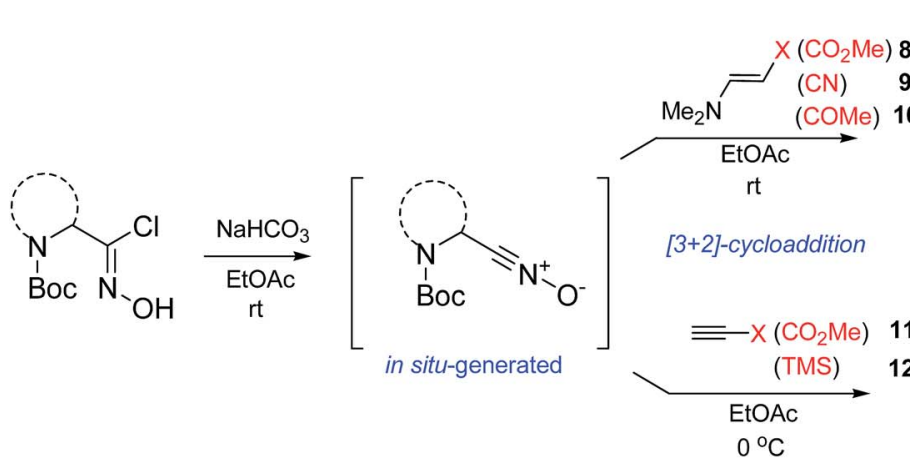

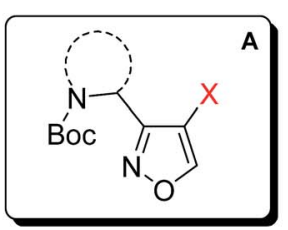

via

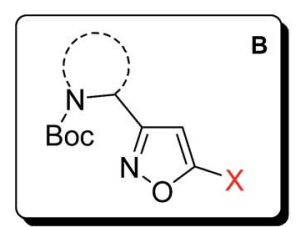

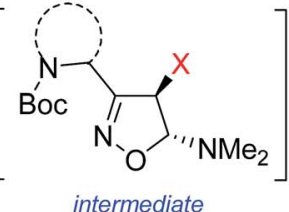

intermediate

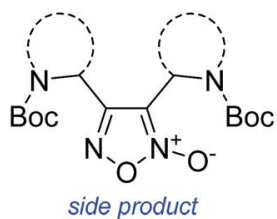

in one synthesis run

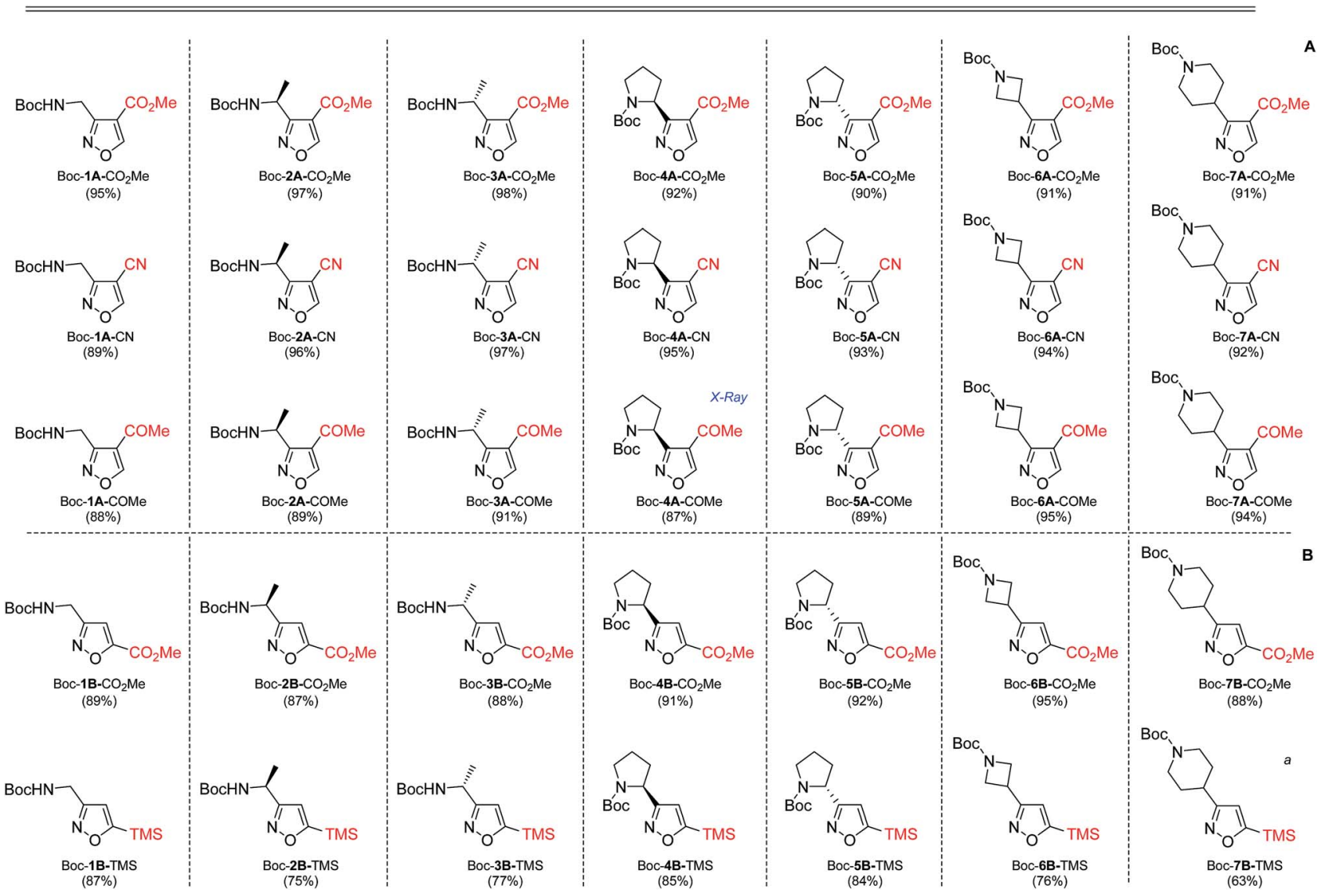

${ }^{a} \mathrm{Et}_{3} \mathrm{~N}$ was used instead of $\mathrm{NaHCO}_{3}$ to generate the nitrile oxide, 5 eq. of $\mathbf{1 2}$ were used.

ring is generally afforded in nature by cyclization of serine or threonine side chain on the downstream amide bond..$^{32-34}$ Total synthesis of respective peptidomimetics has been developed in order to provide naturally occurring antimicrobial agents or toxins as well as their chemically modified analogues..$^{35,36}$ Though, oxa/thiazole to isoxazole mutations have not been explored. Therefore, next we attempted the synthesis of isoxazole-containing peptidomimetics by solid phase peptide synthesis (SPPS) in order to highlight this opportunity.

Initially we synthesized the Fmoc-protected amino acid Fmoc-AlaIso-OH (17) (Scheme 3). Peptide chains were grown on Rink-amide resin, and TBTU/HOBt/DIPEA system was used for coupling. Only in the case of Ac-Leu-AlaIso-Val- $\mathrm{NH}_{2}(\mathbf{1 8})$ we observed minor degree of epimerization $(\leq 15 \%)$, whereas in Ac- 
Table 3 Cleavage of TMS-group from the isoxazole ring
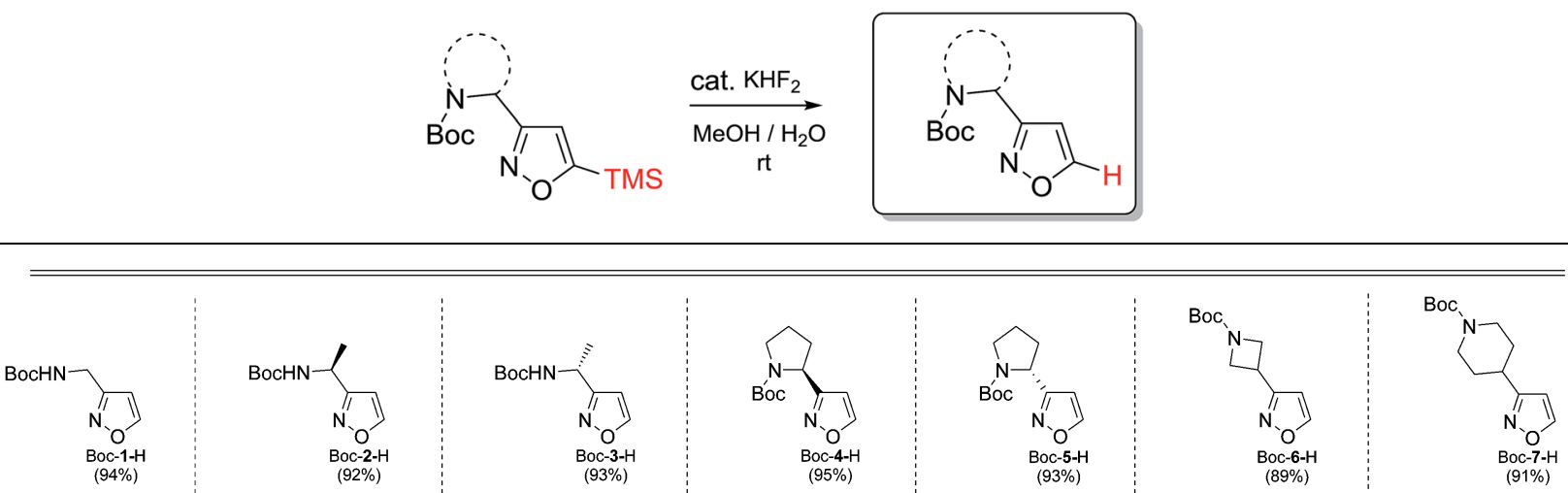

Leu-Val-AlaIso- $\mathrm{NH}_{2}$ (19) no racemization was observed. ${ }^{37}$ In Fmoc-AlaIso-OH turned out to be compatible with the standard addition, no degradation was found after cleavage from the SPPS, allowing synthesis and isolation of both target peptides resin upon treatment with TFA/TIS. Generally the amino acid by conventional methods. ${ }^{38}$

Table 4 Cleavage of the $\mathrm{N}$-Boc protection group from the amino moiety
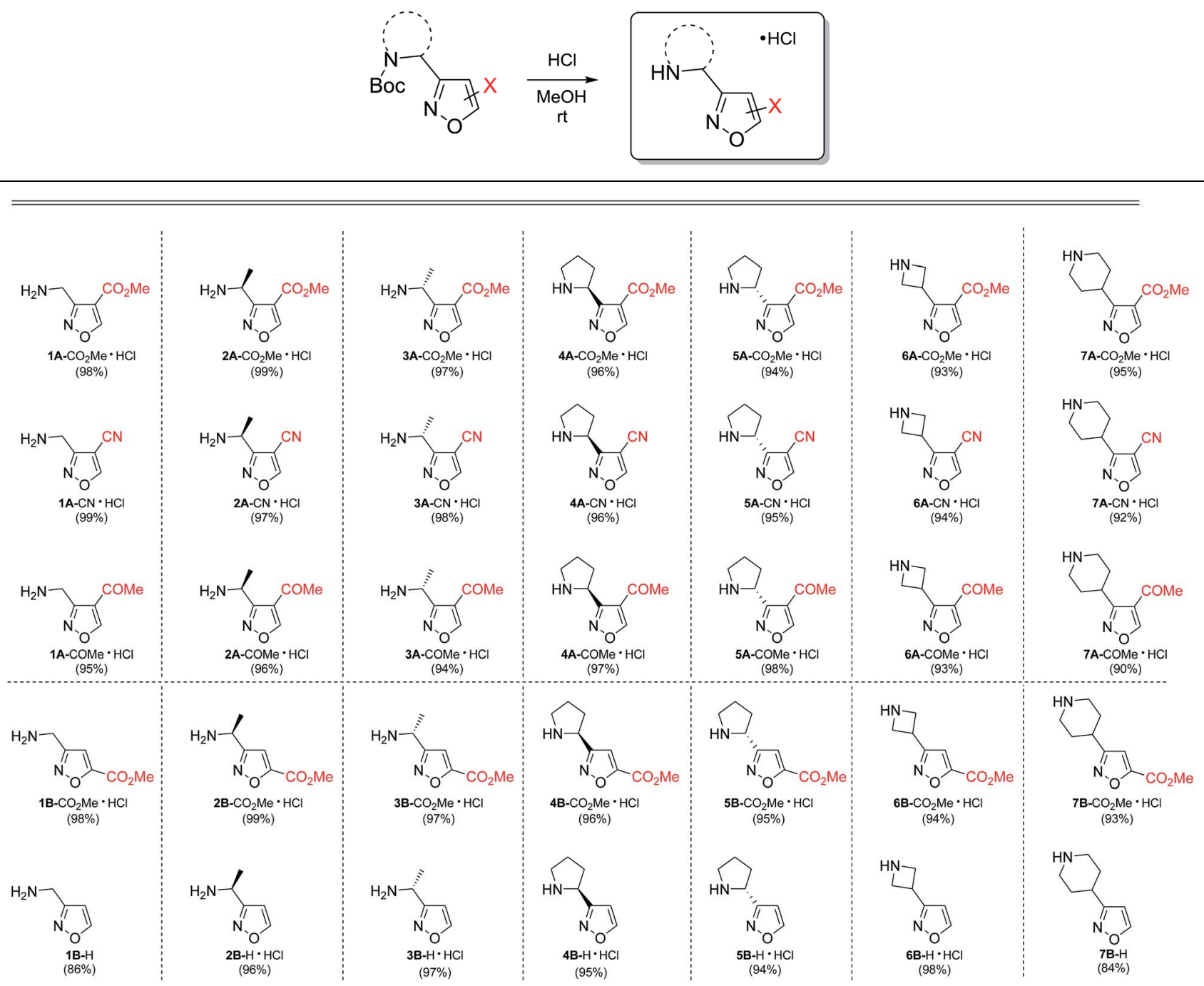
Table 5 Synthesis of isoxazole-containing amino acids
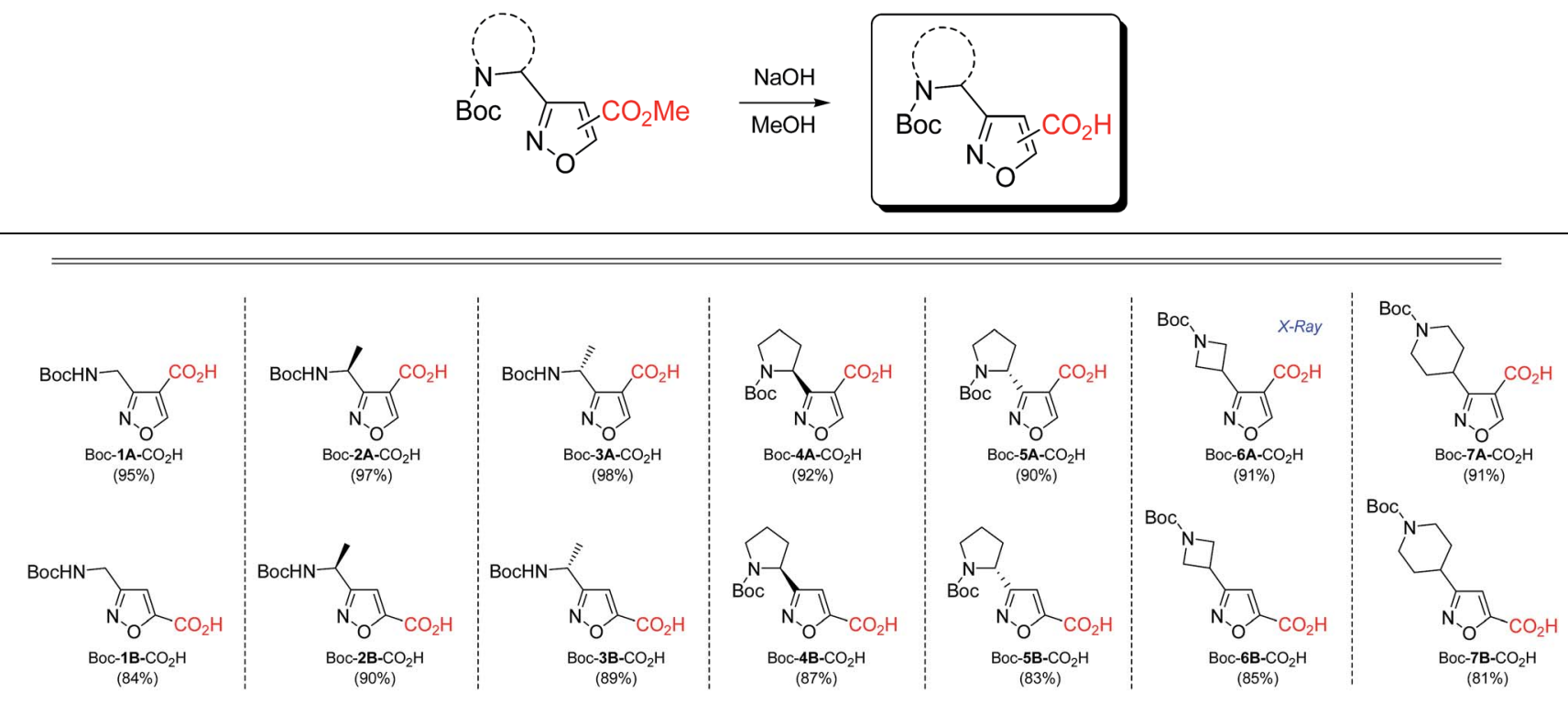

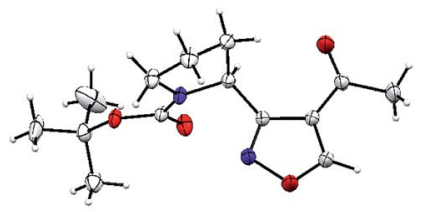

Boc-4A-COMe

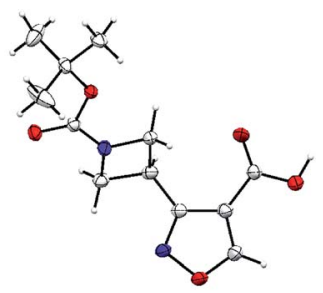

Boc-6A- $\mathrm{CO}_{2} \mathrm{H}$

Fig. 2 X-ray crystal structures of Boc-4A-COMe and Boc- $6 \mathrm{~A}-\mathrm{CO}_{2} \mathrm{H}$.

\section{Conclusions}

We have developed a general metal-free practical protocol towards isoxazole-containing building blocks starting from commonly available $\alpha$-, $\beta$ - and $\gamma$-amino acids. The target products were obtained in up to $50 \mathrm{~g}$ scale. The high potential of the developed method was demonstrated by synthesis of compound 16 - bioisostere of the known nootropic agent ABT418, - and preparation of isoxazole-containing peptidomimetics 18,19 by solid phase peptide synthesis.

\section{Experimental section}

\section{General}

All reagents were available from Enamine Ltd. Solvents were purified according to standard procedures. When organic solutions were concentrated under reduced pressure, $35-40{ }^{\circ} \mathrm{C}$ bath temperature was used. Column chromatography was performed

a)

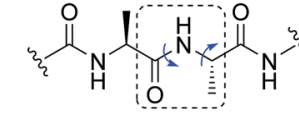

$$
\alpha \text {-Peptide }
$$$$
\text { conformationally flexible }
$$<smiles>C1=C2CCC(CC1)C2</smiles><smiles>CCC(=O)NC(C)c1cc(C(=O)NC)no1</smiles>

$\alpha$-Peptidomimetic conformationally restricted

b)<smiles>CCC(=O)N[C@@H](C)C(=O)N[C@@H](CO)C(=O)NC</smiles>

genetically encoded post-translationally modified

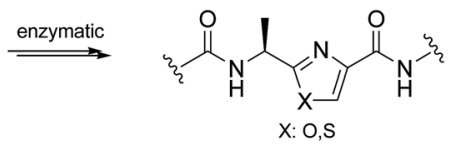

Scheme 2 (a) $\alpha$-Peptide, and its conformationally-restricted analogue with isoxazole backbone; (b) construction of a post-translationally modified peptide with oxa/thiasole backbone.

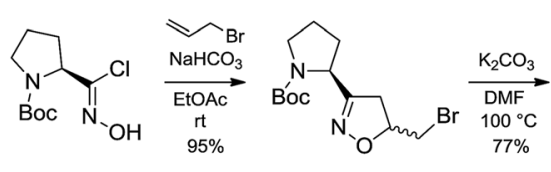

4

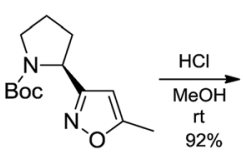

14
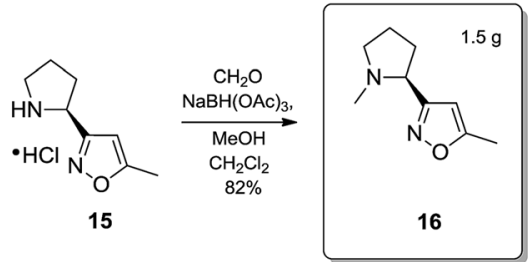

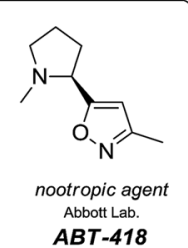

Scheme 1 Synthesis of isoxazole 16 - bioisostere of the known nootropic agent ABT-418. 


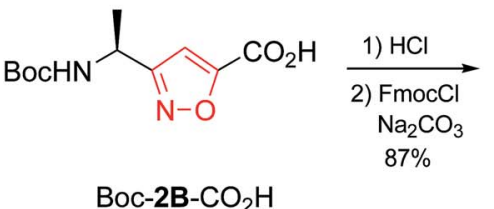

Boc-2B- $\mathrm{CO}_{2} \mathrm{H}$

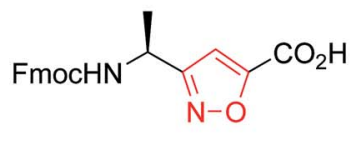

17

(Fmoc-Alalso-OH)<smiles>CC(=O)N[C@@H](CC(C)C)C(=O)N[C@@H](C)c1cc(C(=O)N[C@H](C(N)=O)C(C)C)on1</smiles>

18
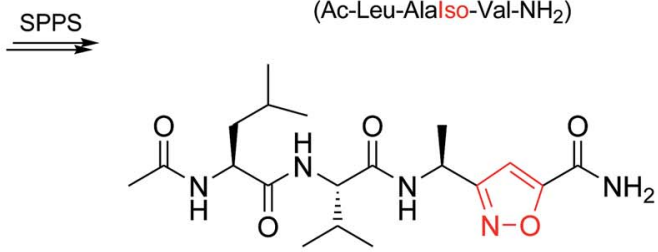

19

(Ac-Leu-Val-Alalso- $\mathrm{NH}_{2}$ )

Scheme 3 Synthesis of isoxazole-containing peptidomimetics 18 and 19

with silica gel $60\left(230-400\right.$ mesh) as the stationary phase. ${ }^{1} \mathrm{H},{ }^{13} \mathrm{C}$ NMR spectra were recorded at the NMR spectrometers operating at 400 and $500{ }^{1} \mathrm{H}$ frequency (101 and $126 \mathrm{MHz}$ for ${ }^{13} \mathrm{C}$ experiments). NMR chemical shifts are reported in ppm, in the $\delta$ scale and are referenced using residual NMR solvent peaks at 7.26 and $77.16 \mathrm{ppm}$ for ${ }^{1} \mathrm{H}$ and ${ }^{13} \mathrm{C}$ in $\mathrm{CDCl}_{3}, 2.50$ and $39.52 \mathrm{ppm}$ for ${ }^{1} \mathrm{H}$ and ${ }^{13} \mathrm{C}$ in DMSO- $d_{6}$, and $4.79 \mathrm{ppm}$ for ${ }^{1} \mathrm{H}$ in $\mathrm{D}_{2} \mathrm{O}$. For peptides NMR analysis was performed in $5 \mathrm{mM}$ peptide solutions in $\mathrm{CD}_{3} \mathrm{OD}$ at $700 \mathrm{MHz}\left({ }^{1} \mathrm{H}\right.$ frequency) spectrometer. ${ }^{1} \mathrm{H}$ NMR spectra were recorded $25 \mathrm{~min}$ after the peptides were dissolved (fresh) and therefore contained few of the non-exchanged amide resonances. The ${ }^{1} \mathrm{H}$ NMR spectra were in addition recorded after overnight measurements when the NH-to-ND exchange was already completed. ${ }^{1} \mathrm{H}$ HOHAHA (dipsi2 of $60 \mathrm{~ms}$ ) and ROESY (spin-lock $300 \mathrm{~ms}$ ) spectra were recorded to complete the assignment of the ${ }^{1} \mathrm{H}$ resonances. ${ }^{13} \mathrm{C}\left\{{ }^{1} \mathrm{H}\right\}$ dept 45 and ${ }^{1} \mathrm{H}\left\{{ }^{13} \mathrm{C}\right\}$ HSQC experiments were performed in order to assign accompanied ${ }^{13} \mathrm{C}$ resonances. The following abbreviations are used in reported NMR data: $\mathrm{s}$ (singlet), d (doublet), $\mathrm{t}$ (triplet), $\mathrm{q}$ (quadruplet), m (multiplet), br (broad), brs (broad singlet). Coupling constants $(J)$ are in Hz. Spectra are reported as follows: chemical shift $(\delta, \mathrm{ppm})$, multiplicity, integration, coupling constants $(\mathrm{Hz})$. Measured melting points are uncorrected. Boiling points were measured at $0.8 \mathrm{mmHg}$ unless otherwise specified herein. LC-MS data were acquired on Agilent 1200 HPLC system equipped with DAD/ELSD/LCMS-6120 diodematrix and mass-selective detector, column: Poroshell 120 SBC18, $4.6 \mathrm{~mm} \times 30 \mathrm{~mm}$. Eluent, A, acetonitrile-water with $0.1 \%$ of FA ( $99: 1)$; B, water with $0.1 \%$ of FA. Optical rotations were measured on polarimeter in methanol using $1 \mathrm{dm}$ cell; optical rotation values are given in $10^{-1} \mathrm{deg} \mathrm{cm}^{2} \mathrm{~g}^{-1}$; concentrations $(c)$ are given in $\mathrm{mmol} \mathrm{L}^{-1}$, wavelength $589 \mathrm{~nm}$ at $20^{\circ} \mathrm{C}$. The enantiomeric excess and retention time $\left(t_{\mathrm{R}}\right)$ was determined for major signal by HPLCs: Daicel CHIRALPACK IA, $5 \mu \mathrm{m}, 4.6 \times 250 \mathrm{~mm}$, Daicel CHIRALPACK IB, $5 \mu \mathrm{m}, 4.6 \times 250 \mathrm{~mm}$, Daicel CHIRALPACK OJ-H, $5 \mu \mathrm{m}, 4.6 \times 250 \mathrm{~mm}$, Daicel CHIRALPACK AS-H, 5 $\mu \mathrm{m}, 4.6 \times 250 \mathrm{~mm}$ chiral columns, injection volume $0.1 \mu \mathrm{L}$, eluent (hexanes: 2-propanol). Solid compounds were recrystallized from acetonitrile unless other is specified.

\section{Synthesis of 3,4-disubstituted isoxazoles, representative procedure}

Methyl 3-((tert-butoxycarbonyl)amino)methyl)isoxazole-4carboxylate (Boc-1A-CO $\left.\mathrm{CO}_{2} \mathrm{Me}\right)$. A $250 \mathrm{~mL}$ round bottomed flask was charged with a magnetic stirrer, corresponding chloroxime $1(2 \mathrm{~g}, 9.6 \mathrm{mmol})$ and EtOAc $(20 \mathrm{~mL})$. To the resulting vigorously stirred homogeneous solution (E)-methyl 3-(dimethylamino) acrylate $8(1.48 \mathrm{~g}, 11.5 \mathrm{mmol})$ was added followed by addition of $\mathrm{NaHCO}_{3}(1.6 \mathrm{~g}, 19.2 \mathrm{mmol})$ at the ambient temperature. The resulting mixture was stirred overnight. The progress of the reaction was monitored by NMR spectroscopy. After the reaction was complete, the organic phase was washed with $10 \%$ $\mathrm{NaHSO}_{4(\mathrm{aq})}(3 \times 5 \mathrm{~mL}), 10 \% \mathrm{~K}_{2} \mathrm{CO}_{3(\mathrm{aq})}(2 \times 5 \mathrm{~mL})$ and brine $(1 \times$ $5 \mathrm{~mL}$ ). Organic phase was dried over anhydrous $\mathrm{Na}_{2} \mathrm{SO}_{4}$. The resulting mixture was filtered through a silicagel pad and concentrated to yield $\mathbf{B o c}-\mathbf{1 A}-\mathbf{C O}_{2} \mathbf{M e}(95 \%, 2.3 \mathrm{~g})$ as a beige powder, mp $65^{\circ} \mathrm{C}$.

${ }^{1} \mathrm{H}$ NMR $\left(500 \mathrm{MHz}\right.$, DMSO- $\left.d_{6}\right): \delta 9.59(\mathrm{~s}, 1 \mathrm{H}$, isoxaz), 7.24 (brs, $1 \mathrm{H}, \mathrm{NH}), 4.41\left(\mathrm{~d}, 2 \mathrm{H}, \mathrm{CH}_{2}\right), 3.80\left(\mathrm{~s}, 3 \mathrm{H}, \mathrm{OCH}_{3}\right), 1.39\left(\mathrm{~s}, 9 \mathrm{H}, \mathrm{CH}_{3^{-}}\right.$ Boc). ${ }^{13} \mathrm{C}$ NMR (125 MHz, DMSO- $d_{6}$ ): $\delta$ 164.9, 161.1, 160.0, 155.4, 111.9, 78.2, 51.9, 35.9, 28.1. MS (APCI) $m / z[\mathrm{M}-\mathrm{Boc}+1 \mathrm{H}]^{+}$ calculated for $\mathrm{C}_{10} \mathrm{H}_{13} \mathrm{~N}_{2} \mathrm{O}_{5}$ : 255.1; found: 255.4. Anal. calcd for $\mathrm{C}_{11} \mathrm{H}_{16} \mathrm{~N}_{2} \mathrm{O}_{5}$ : C, 51.56; H, 6.29; N, 10.93. Found: C, 51.35; H, $6.07 ; \mathrm{N}, 10.52$.

\section{Synthesis of 3,5-disubstituted isoxazoles, representative procedure}

Methyl 3-(((tert-butoxycarbonyl)amino)methyl)isoxazole-5carboxylate (Boc-1B- $\mathrm{CO}_{2} \mathrm{Me}$ ). A $250 \mathrm{~mL}$ round bottomed flask was charged with a magnetic stirrer, corresponding chloroxime $1(2 \mathrm{~g}, 9.6 \mathrm{mmol})$ and EtOAc $(20 \mathrm{~mL})$. Then, the resulting vigorously stirred homogeneous solution was cooled to $-5-0{ }^{\circ} \mathrm{C}$ and methyl propiolate $(0.9 \mathrm{~mL}, 10.1 \mathrm{mmol})$ was added followed by addition of $\mathrm{NaHCO}_{3}(1.6 \mathrm{~g}, 19.2 \mathrm{mmol})$ (in case of reaction 7 $(2 \mathrm{~g}, 7.6 \mathrm{mmol})$ with ethynyltrimethylsilane $12(5.4 \mathrm{~mL}, 38$ mmol) dropwise addition of $\mathrm{Et}_{3} \mathrm{~N}(1.6 \mathrm{~mL}, 11.5 \mathrm{mmol})$ as a solution in EtOAc $(100 \mathrm{~mL})$ was required). The resulting mixture was stirred overnight. The progress of the reaction was 
monitored by NMR spectroscopy. Work-up was done by simple filtration through silica pad, then the resulting solution was concentrated and dried in vacuo to yield the corresponding product Boc-1B-C $\mathbf{O}_{2} \mathbf{M e}(89 \%, 2.2 \mathrm{~g})$ as a white powder, mp 84$86{ }^{\circ} \mathrm{C}$. For reaction of compound 7 with 12 when the reaction was complete, the organic phase was washed with $10 \%$ $\mathrm{K}_{2} \mathrm{CO}_{3(\mathrm{aq})}(2 \times 20 \mathrm{~mL})$ and brine $(1 \times 20 \mathrm{~mL})$. Organic phase was dried over anhydrous $\mathrm{Na}_{2} \mathrm{SO}_{4} \cdot{ }^{1} \mathrm{H}$ NMR (500 MHz, DMSO- $d_{6}$ ): $\delta 7.49$ (s, 1H, NH), 7.05 (s, 1H, isoxaz), 4.24-4.23 (d, 2H, $J=5.5$, $\mathrm{CH}_{2}$ ), 3.89 (s, 3H, $\mathrm{OCH}_{3}$ ), 1.39 (br, 9H, $\left.\mathrm{CH}_{3}-\mathrm{Boc}\right) .{ }^{13} \mathrm{C}$ NMR (125 MHz, DMSO- $\left.d_{6}\right): \delta 163.7,159.5,156.7,155.7,109.0,78.5,52.9$, 35.6, 28.1. MS (APCI) $m / z[\mathrm{M}-\text { Boc }+1 \mathrm{H}]^{+}$calculated for $\mathrm{C}_{10} \mathrm{H}_{13} \mathrm{~N}_{2} \mathrm{O}_{5}$ : 255.1; found: 255.4. Anal. calcd for $\mathrm{C}_{11} \mathrm{H}_{16} \mathrm{~N}_{2} \mathrm{O}_{5}: \mathrm{C}$, 51.56; H, 6.29; N, 10.93. Found: C, 51.27; H, 6.54; N, 10.63.

\section{Representative procedure for cleavage of tert-butyloxycarbonyl group}

1-(3-(Aminomethyl)isoxazol-4-yl)ethan-1-one hydrochloride (1A-COMe-HCl). A $250 \mathrm{~mL}$ round bottomed flask was charged with a magnetic stirrer, corresponding Boc-protected isoxazole Boc-1A-COMe (2.5 g, $9.8 \mathrm{mmol})$ and EtOAc $(25 \mathrm{~mL})$. The flask was submerged into an ice cooling bath; and to the vigorously stirred homogeneous solution equimolar ratio of $\mathrm{MeOH}$ (1.05 eq.) was added followed by dropwise addition of $\mathrm{AcCl}$ (1.05 eq.). As the result white precipitate was formed. After the reaction was complete (NMR control) resulting solid was filtered and washed with cold EtOAc and recrystallized from MeCN (if it was necessary) affording $\mathbf{1 A}-\mathbf{C O M e} \cdot \mathbf{H C l}$ as a white powder. In case of EWG $=\mathrm{CO}_{2} \mathrm{Me}$-group AcCl (1.05 eq.) in $\mathrm{MeOH}$ was used.

1A-COMe-HCl: $95 \%$, white powder, mp 94-96 ${ }^{\circ} \mathrm{C} .{ }^{1} \mathrm{H}$ NMR $\left(500 \mathrm{MHz}, \mathrm{D}_{2} \mathrm{O}-d_{2}\right): \delta 9.53\left(\mathrm{~s}, 1 \mathrm{H}\right.$, isoxaz), $4.54\left(\mathrm{~s}, 2 \mathrm{H}, \mathrm{CH}_{2}\right), 2.60$ (s, 3H, $\mathrm{CH}_{3}$-Ac). ${ }^{13} \mathrm{C}$ NMR (125 MHz, DMSO- $\left.d_{6}\right): \delta$ 192.0, 166.1, 155.9, 119.8, 34.4, 29.0. MS (APCI) $m / z[\mathrm{M}+1 \mathrm{H}]^{+}$calculated for $\mathrm{C}_{6} \mathrm{H}_{9} \mathrm{~N}_{2} \mathrm{O}_{2}$ : 141.1; found: 141.2. Anal. calcd for $\mathrm{C}_{6} \mathrm{H}_{9} \mathrm{ClN}_{2} \mathrm{O}_{2}: \mathrm{C}$, 40.81; H, 5.14; N, 15.86. Found: C, 40.25; H, 5.33; N, 15.96.

\section{Representative procedure for the hydrolysis of isoxazole-based esters}

3-(((tert-Butoxycarbonyl)amino)methyl)isoxazole-4-carboxylic acid (Boc-1A-CO $\mathbf{O}_{2} \mathbf{H}$ ). A $250 \mathrm{~mL}$ round bottomed flask was charged with a magnetic stirrer, corresponding isoxazole (Boc1A-CO $\mathbf{C e}, 2 \mathrm{~g}, 7.8 \mathrm{mmol})$ and $\mathrm{MeOH}(18 \mathrm{~mL})$. Next, the flask was submerged into an ice cooling bath and to the resulting vigorously stirred homogeneous solution 2 equiv. of $10 \%$ $\mathrm{NaOH}_{(\mathrm{aq})}$ was added dropwise. After the NMR control indicated the reaction completion (10-24 h), the solution was concentrated in vacuo. $\mathrm{HCl}_{(\mathrm{aq})}$, or $\mathrm{NaHSO}_{4(\mathrm{aq})}$, was added dropwise until $\mathrm{pH}=3$ was reached and solid $\mathrm{NaCl}$ was added until the resulting solution become saturated. The product was extracted by EtOAc $(3 \times 20 \mathrm{~mL})$. Combined organic fractions were dried over anhydrous $\mathrm{MgSO}_{4}$, concentrated and dried in vacuo yielding Boc-1A- $\mathbf{C O}_{2} \mathbf{H}$ as a white powder, (95\%, $\left.1.8 \mathrm{~g}\right)$, mp 129$131{ }^{\circ} \mathrm{C} .{ }^{1} \mathrm{H}$ NMR (500 MHz, DMSO- $d_{6}$ ): $\delta 13.25$ (br, $1 \mathrm{H}, \mathrm{C}-\mathrm{OOH}$ ), 9.45 (s, 1H, isoxaz), 7.17 (brs, $1 \mathrm{H}$, NH-major rotamer), 6.80 (brs, $\mathrm{NH}$-minor of rotamer $), 4.40\left(\mathrm{~d}, 2 \mathrm{H}, \mathrm{J}=4.5, \mathrm{CH}_{2}\right), 1.38\left(\mathrm{~s}, 9 \mathrm{H}, \mathrm{CH}_{3}-\right.$ Boc). ${ }^{13} \mathrm{C}$ NMR $\left(125 \mathrm{MHz}\right.$, DMSO- $\left.d_{6}\right): \delta 164.6,162.4,160.3,155.5$,
113.2, 78.2, 36.1, 28.2. MS (APCI) $m / z[\mathrm{M}-1 \mathrm{H}]^{+}$calculated for $\mathrm{C}_{10} \mathrm{H}_{13} \mathrm{~N}_{2} \mathrm{O}_{5}$ : 241.1; found: 241.2. Anal. calcd for $\mathrm{C}_{10} \mathrm{H}_{14} \mathrm{~N}_{2} \mathrm{O}_{5}: \mathrm{C}$, 49.58; H, 5.83; N, 11.56. Found: C, 49.38; H, 5.66; N, 11.43.

\section{Representative procedure for the for the synthesis of 3- substituted isoxazoles}

tert-Butyl (isoxazol-3-ylmethyl)carbamate (Boc-1-H). A round bottomed flask $(100 \mathrm{~mL})$ was charged with a magnetic stirrer, substrate Boc-1-H-TMS (5.5 g, $20.3 \mathrm{mmol})$ and $\mathrm{MeOH}(25 \mathrm{~mL})$. $\mathrm{KHF}_{2} 5 \mathrm{~mol} \%(80 \mathrm{mg}, 1 \mathrm{mmol})$ with $\mathrm{H}_{2} \mathrm{O}_{\text {(cat) }}(100 \mu \mathrm{L})$ were added and the resulting homogeneous solution was vigorously stirred for $24 \mathrm{~h}$ at the ambient temperature while the progress was monitored by NMR spectroscopy. After the reaction was completed the solvent was evaporated and the remaining residue was dissolved in EtOAc $(50 \mathrm{~mL})$. Organic phase was filtered through anhydrous $\mathrm{Na}_{2} \mathrm{SO}_{4}$ pad and concentrated to yield Boc-1-H as a white powder (94\%, $3.8 \mathrm{~g}) .{ }^{1} \mathrm{H} \mathrm{NMR}(500 \mathrm{MHz}$, DMSO- $\left.d_{6}\right): \delta 8.79(\mathrm{~m}, 1 \mathrm{H}, \mathrm{CH}$-isoxaz), 7.43-7.35 (brs, $1 \mathrm{H}, \mathrm{NH}$ ), 6.42 (s, $1 \mathrm{H}$, isoxaz), 4.20-4.19 (m, 2H, $\left.\mathrm{CH}_{2}\right), 1.39$ (s, 9H, $\mathrm{CH}_{3}-$ Boc). ${ }^{13} \mathrm{C}$ NMR (125 MHz, DMSO- $\left.d_{6}\right): \delta 161.5,159.8,155.7,103.8$, 78.3, 35.5, 28.2. Anal. calcd for $\mathrm{C}_{9} \mathrm{H}_{14} \mathrm{~N}_{2} \mathrm{O}_{3}$ : C, 54.53; H, 7.12; N, 14.13. Found: C, 54.36; H, 7.18; N, 14.01 .

\section{Synthesis of the ABT-418 bioisostere 16}

tert-Butyl (2S)-2-(5-(bromomethyl)-4,5-dihydroisoxazol-3-yl) pyrrolidine-1-carboxylate (13). A $500 \mathrm{~mL}$ round bottomed flask was charged with a magnetic stirrer, corresponding chloroxime 4 (10 g, $40.2 \mathrm{mmol})$ and EtOAc $(100 \mathrm{~mL})$. To the resulting vigorously stirred homogeneous solution allyl bromide (5.6 g, $46.23 \mathrm{mmol}$ ) was added followed by addition of $\mathrm{NaHCO}_{3}(6.7 \mathrm{~g}$, $80.4 \mathrm{mmol}$ ). The resulting mixture was stirred overnight. The progress of the reaction was monitored by NMR spectroscopy. After the reaction was complete, organic phase was dried over anhydrous $\mathrm{Na}_{2} \mathrm{SO}_{4}$ and filtered through the silica gel pad. The resulting solution was concentrated to yield $13(95 \%, 12.95 \mathrm{~g})$ as a white powder, $\mathrm{mp} 60^{\circ} \mathrm{C}$.

13-S-Isomer: $95 \%$, white powder, $[\alpha]_{\mathrm{D}}^{20}=-80.00(c=35.42)$. $99.6 \%$ ee, $t_{\mathrm{R}}=12.2 \mathrm{~min}$;

13- $R$-Isomer: $97 \%$, white powder, $[\alpha]_{\mathrm{D}}^{20}=+81.84(c=35.42)$, $99.8 \%$ ee, $t_{\mathrm{R}}=10.5 \mathrm{~min}$.

${ }^{1} \mathrm{H}$ NMR $\left(500 \mathrm{MHz}, \mathrm{CDCl}_{3}\right): \delta 4.85-4.78(\mathrm{~m}, 1 \mathrm{H}$, isoxazoline$\mathrm{CH}$ ), 4.63 (brs, $1 \mathrm{H}$, -pyrrolidine- $\mathrm{CH}), 3.48-3.32\left(\mathrm{~m}, 4 \mathrm{H}, \mathrm{CH}_{2}-\right.$ pyrrolidine $\left.+\mathrm{CH}_{2}-\mathrm{Br}\right), 2.94-2.90\left(\mathrm{~m}, 2 \mathrm{H}, \mathrm{CH}_{2}\right.$-isoxazoline $), 2.17-$ $1.91\left(\mathrm{~m}, 4 \mathrm{H}, \mathrm{CH}_{2}\right.$-pyrrolidine), 1.46 (s, 9H, $\left.\mathrm{CH}_{3}-\mathrm{Boc}\right) .{ }^{13} \mathrm{C} \mathrm{NMR}$ (125 MHz, DMSO- $d_{6}$, mixture of both rotamers): $\delta 160.3,159.7$, 153.5, 153.1, 78.8, 78.3, 54.0, 46.3, 46.0, 38.7, 35.7, 35.2, 34.8, 30.4 , 30.2 29.6, 29.3, 28.0, 23.9, 23.0. MS (APCI) $m / z[\mathrm{M}-\text { Boc }]^{+}$ calculated for $\mathrm{C}_{8} \mathrm{H}_{13} \mathrm{BrN}_{2} \mathrm{O}: 235.0$; found: 235.1. Anal. calcd for $\mathrm{C}_{13} \mathrm{H}_{21} \mathrm{BrN}_{2} \mathrm{O}_{3}$ : C, 46.86; H, 6.35; N, 8.41. Found: C, 46.77; H, $6.44 ; \mathrm{N}, 8.57$.

tert-Butyl (S)-2-(5-methylisoxazol-3-yl)pyrrolidine-1-carboxylate (14). A $250 \mathrm{~mL}$ round bottomed flask was charged with a magnetic stirrer, corresponding isoxazoline 13 (12.5 g, 37.5 $\mathrm{mmol}$ ) and DMF (50 mL). $\mathrm{K}_{2} \mathrm{CO}_{3}(10.4 \mathrm{~g}, 75 \mathrm{mmol})$ was added and the resulting mixture was stirred overnight at $100{ }^{\circ} \mathrm{C}$. The progress of the reaction was monitored by NMR spectroscopy. 
After the reaction was complete, the reaction mixture was concentrated the residue was poured into ice-bath and aqueous phase was extracted with EtOAc. The combined orhanic phases were washed with brine $(4 \times 20 \mathrm{~mL})$. Organic phase was dried over anhydrous $\mathrm{Na}_{2} \mathrm{SO}_{4}$. The resulting mixture was filtered through the silicagel pad and the solution was concentrated. The residue is colorless oil which was solidified upon standing $77 \%$.

14-S-Isomer: $77 \%,[\alpha]_{\mathrm{D}}^{20}=-78.8(c=3.96), 99.9 \%$ ee, $t_{\mathrm{R}}=9.5$ $\min$;

14- $R$-Isomer: $75 \%,[\alpha]_{\mathrm{D}}^{20}=+79.63(c=3.96), 99.9 \%$ ee, $t_{\mathrm{R}}=$ $7.6 \mathrm{~min}$

${ }^{1} \mathrm{H}$ NMR (500 MHz, DMSO- $d_{6}$ ): $\delta 6.10$ (brs, $1 \mathrm{H}$, isoxaz), 4.834.77 (m, 1H, CH-pyrrolidine), 3.43-3.38 (m, 2H, CH dine), 2.36 (s, 3H, $\mathrm{CH}_{3}$ ), 2.21 (br, $1 \mathrm{H}, \mathrm{CH}$-pyrrolidine), 1.85 (br, $3 \mathrm{H}, \mathrm{CH}$-pyrrolidine), 1.39, (s, 9H, $\mathrm{CH}_{3}$-Boc, major rotamer), 1.24 (s, 9H, $\mathrm{CH}_{3}$-Boc, minor rotamer). ${ }^{13} \mathrm{C}$ NMR (125 MHz, DMSO- $\left.d_{6}\right)$ : $\delta$ 169.02, 166.4 166.0, 153.5, 153.2, 100.4, 99.8, 78.6, 78.5, 53.3, 53.1, 46.3, 46.0, 32.6, 31.3, 28.1, 27.9, 23.6, 22.9, 11.7.

MS (APCI) $m / z[\mathrm{M}+3 \mathrm{H}]^{+}$calculated for $\mathrm{C}_{13} \mathrm{H}_{23} \mathrm{~N}_{2} \mathrm{O}_{3}: 255.3$; found: 255.2. Anal. calcd for $\mathrm{C}_{13} \mathrm{H}_{20} \mathrm{~N}_{2} \mathrm{O}_{3}$ : C, 61.88; H, 7.99; N, 11.10. Found: C, 61.95; H, 7.83; N, 11.14.

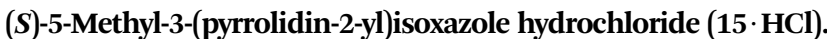
The same experimental procedure as previously described for 3,4- and 3,5-analogues for the cleavage of Boc-group was used.

15- $S$-Isomer, white powder, 92\%, $[\alpha]_{\mathrm{D}}^{20}=-21.63(c=53.00)$; 15- $R$-Isomer, white powder, 93\%, $[\alpha]_{\mathrm{D}}^{20}=+22.95(c=53.00)$.

${ }^{1} \mathrm{H}$ NMR (500 MHz, DMSO- $\left.d_{6}\right): \delta 10.63(\mathrm{br}, 1 \mathrm{H}, \mathrm{NH} \cdot \mathrm{HCl}$ ), 9.57 (br, $1 \mathrm{H}, \mathrm{NH} \cdot \mathrm{HCl}$ ), 6.55 (s, 1H, isoxaz), 4.66 (brs, $1 \mathrm{H}, \mathrm{CH}$ ), 3.27$3.22\left(\mathrm{~m}, 2 \mathrm{H}, \mathrm{CH}_{2}\right.$-pyrrolidine), $2.43\left(\mathrm{~s}, 3 \mathrm{H}, \mathrm{CH}_{3}\right), 2.35-2.33(\mathrm{~m}$, 1H, CH-pyrrolidine), 2.02 (br, 3H, CH- -pyrrolidine). ${ }^{13} \mathrm{C}$ NMR (125 MHz, DMSO- $d_{6}$ ): $\delta 170.6,160.1,101.4,54.0,44.4,29.4,22.8$, 11.9. MS (APCI) $m / z[\mathrm{M}-\mathrm{Cl}+\mathrm{H}]^{+}$calculated for $\mathrm{C}_{8} \mathrm{H}_{19} \mathrm{~N}_{2} \mathrm{O}$ : 153.1; found: 153.2. Anal. calcd for $\mathrm{C}_{8} \mathrm{H}_{13} \mathrm{ClN}_{2} \mathrm{O}: \mathrm{C}, 50.93 ; \mathrm{H}$, $6.95 ; \mathrm{N}, 14.85$. Found: C, 50.87; H, 7.08; N, 14.89 .

(S)-5-Methyl-3-(1-methylpyrrolidin-2-yl)isoxazole (16). A 500 $\mathrm{mL}$ round bottomed flask was charged with magnetic stirrer and corresponding isoxazole $15(2.1 \mathrm{~g}, 10.60 \mathrm{mmol})$ which was suspended in dichloroethane $(250 \mathrm{~mL})$. MeOH $(50 \mathrm{~mL})$ was added followed by addition of $30 \% \mathrm{CH}_{2} \mathrm{O}_{(\mathrm{aq})}(10 \mathrm{~mL})$ and $\mathrm{NaBH}(\mathrm{OAC})_{3}(7.0 \mathrm{~g}, 33.03 \mathrm{mmol})$. Then, the resulting mixture was stirred overnight at the ambient temperature. Next, the reaction mixture was concentrated, EtOAc $(250 \mathrm{~mL})$ was added and $\mathrm{K}_{2} \mathrm{CO}_{3}$ was added until the $\mathrm{pH}=10$ was reached (Caution: carbon dioxide evolution!). The reaction mixture was then stirred over $\mathrm{Na}_{2} \mathrm{SO}_{4}$ for $c a .10 \mathrm{~min}$ filtered and concentrated. The product was purified by distillation yielding 16 (1.52 g, bp 75-80 ${ }^{\circ} \mathrm{C}$ at $5.5 \mathrm{mmHg}$ ) as a colorless liquid (with pyrrolidine odour) which is extremely well soluble in water.

16- $S$-Isomer, $82 \%,[\alpha]_{\mathrm{D}}^{20}=-8.00(c=60.16)$;

16-R-Isomer, $83 \%,[\alpha]_{\mathrm{D}}^{20}=+7.86(c=60.16)$.

${ }^{1} \mathrm{H}$ NMR (500 MHz, DMSO- $d_{6}$ ): $\delta 6.14$ (brs, $1 \mathrm{H}$, isoxaz), 3.243.19 (t, $1 \mathrm{H}, \mathrm{J}=10.0$, CH-pyrrolidine), 3.07-3.03 (m, 1H, CHpyrrolidine), 2.36 (s, 3H, $\left.\mathrm{CH}_{3}-\mathrm{NH}\right), 2.26-2.19(\mathrm{~m}, 1 \mathrm{H}, \mathrm{CH}-$ pyrrolidine), $2.11\left(\mathrm{~s}, 4 \mathrm{H}, \mathrm{CH}_{3}+\mathrm{CH}\right), 1.84-1.71(\mathrm{~m}, 3 \mathrm{H}, \mathrm{CH}-$ pyrrolidine). ${ }^{13} \mathrm{C}$ NMR (125 MHz, DMSO- $\left.d_{6}\right): \delta 169.1,166.1,99.7,61.3$, 56.0, 31.7, 22.4, 11.8. MS (APCI) $m / z[\mathrm{M}+\mathrm{H}]^{+}$calculated for
$\mathrm{C}_{9} \mathrm{H}_{15} \mathrm{~N}_{2} \mathrm{O}$ : 167.1; found: 167.2. Anal. calcd for $\mathrm{C}_{9} \mathrm{H}_{14} \mathrm{~N}_{2} \mathrm{O}$ : C, 65.03; H, 8.49; N, 16.85. Found: C, 65.14; H, 8.33; N, 16.94.

\section{Notes and references}

1 (a) S. Kankala, R. K. Kankala, P. Gundepaka, N. Thota, S. Nerella, M. R. Gangula, H. Guguloth, M. Kagga, R. Vadde and C. S. Vasam, Bioorg. Med. Chem. Lett., 2013, 23, 1306-1309; (b) B. Frølund, A. T. Jørgensen, L. Tagmose, T. B. Stensbøl, H. T. Vestergaard, C. Engblom, U. Kristiansen, C. Sanchez, P. Krogsgaard-Larsen and T. Liljefors, J. Med. Chem., 2002, 45, 2454-2468; (c) S. Dadiboyena and A. Nefzi, Eur. J. Med. Chem., 2010, 45, 4697-4707.

2 J. J. Talley, D. L. Brown, J. S. Carter, M. J. Graneto, C. M. Koboldt, J. L. Masferrer, W. E. Perkins, R. S. Rogers, A. F. Shaffer, Y. Y. Zhang, B. S. Zweifel and K. Seibert, J. Med. Chem., 2000, 43, 775-777.

3 J. B. Carr, H. G. Durham and D. K. Hass, J. Med. Chem., 1977, 20, 934-939.

4 (a) J. I. Andrés, J. Alcázar, J. M. Alonso, R. M. Alvarez, M. H. Bakker, I. Biesmans, J. M. Cid, A. I. De Lucas, J. Fernández, L. M. Font, K. A. Hens, L. Iturrino, I. Lenaerts, S. Martínez, A. A. Megens, J. Pastor, P. C. M. Vermote and T. Steckler, J. Med. Chem., 2005, 48, 2054-2071; (b) H. S. Youn, E. J. Lee, J. E. Lee, W.-K. Park, D.-J. Baek, Y. S. Cho, H. Y. Koh, H. Choo and A. N. Pae, Bull. Korean Chem. Soc., 2009, 30, 1873-1876.

5 (a) M. Ma, Y. Cheng, Z. Xu, P. Xu, H. Qu, Y. Fang, T. Xu and L. Wen, Eur. J. Med. Chem., 2007, 42, 93-98; (b) Ö. TemizArpacı, İ. Yıldız, S. Özkan, F. Kaynak, E. Akı-Şener and İ. Yalçın, Eur. J. Med. Chem., 2008, 43, 1423-1431.

6 (a) W.-T. Li, D.-R. Hwang, C.-P. Chen, C.-W. Shen, C.-L. Huang, T.-W. Chen, C.-H. Lin, Y.-L. Chang, Y.-Y. Chang, Y.-K. Lo, H.-Y. Tseng, C.-C. Lin, J.-S. Song, H.-C. Chen, S.-J. Chen, S.-H. Wu and C.-T. Chen, J. Med. Chem., 2003, 46, 1706-1715; (b) J. Yong, C. Lu and X. Wu, Med. Chem. Commun., 2014, 5, 968-972.

7 N. Jacobsen, L.-E. K. Pedersen and A. Wengel, Pestic. Sci., 1990, 29, 95-100.

8 (a) D. S. Garvey, J. T. Wasicak, M. W. Decker, J. D. Brioni, M. J. Buckley, J. P. Sullivan, G. M. Carrera, M. W. Holladay, S. P. Arneric and M. Williams, J. Med. Chem., 1994, 37, 1055-1059; (b) A. Carenzi, D. Chiarino, D. D. Bella, M. Napoletano, A. Sala, US Pat. 4985428, Jan 15, 1991.

9 M. Koufaki, A. Tsatsaroni, X. Alexi, H. Guerrand, S. Zerva and M. N. Alexis, Bioorg. Med. Chem., 2011, 19, 4841-4850.

10 (a) S. Srivastava, L. K. Bajpai, S. Batra, A. P. Bhaduri, J. P. Maikhuri, G. Gupta and J. D. Dhar, Bioorg. Med. Chem., 1999, 7, 2607-2613; (b) K. A. Kumar and P. Jayaroopa, Int. J. Pharm., Chem. Biol. Sci., 2013, 3(2), 294-304.

11 (a) F. Hu and M. Szostak, Adv. Synth. Catal., 2015, 357, 25832614; (b) M. S. Mohamed Ahmed, K. Kobayashi and A. Mori, Org. Lett., 2005, 7, 4487-4489; (c) T. V. Hansen, P. Wu and V. V. Fokin, J. Org. Chem., 2005, 70, 7761-7764; (d) S. Grecian and V. V. Fokin, Angew. Chem., Int. Ed., 2008, 
47, 8285-8287; (e) A. V. Dubrovskiy, P. Jain, F. Shi, G. H. Lushington, C. Santini, P. Porubsky and R. C. Larock, ACS Comb. Sci., 2013, 15, 193-201; (f) R. Huisgen, Angew. Chem., Int. Ed. Engl., 1963, 2, 565-598; (g) T. M. Vishwanatha and V. V. Sureshbabu, J. Heterocycl. Chem., 2015, 52, 1823-1833; (h) A. Singhal, S. K. R. Parumala, A. Sharma and R. K. Peddinti, Tetrahedron Lett., 2016, 57, 719-722.

12 (a) M. A. Weidner-Wells, T. C. Henninger, S. A. Fraga-Spano, C. M. Boggs, M. Matheis, D. M. Ritchie, D. C. Argentieri, M. P. Wachter and D. J. Hlasta, Bioorg. Med. Chem. Lett., 2004, 14, 4307-4311; (b) S. Dadiboyena and A. Nefzi, Tetrahedron Lett., 2012, 53, 2096-2099; (c) D. E. Kizer, R. B. Miller and M. J. Kurth, Tetrahedron Lett., 1999, 40, 3535-3538; (d) S. Mohammed, R. A. Vishwakarma and S. B. Bharate, $R S C$ Adv., 2015, 5, 3470-3473; (e) P. K. Mykhailiuk, Org. Biomol. Chem., 2015, 13, 3438-3445. 13 (a) R. C. F. Jones, S. J. Hollis and J. N. Iley, Tetrahedron: Asymmetry, 2000, 11, 3273-3276; (b) Y. K. Kang, K. J. Shin, K. H. Yoo, K. J. Seo, C. Y. Hong, C.-S. Lee, S. Y. Park, D. J. Kim and S. W. Park, Bioorg. Med. Chem. Lett., 2000, 10, 95-99; (c) R. C. F. Jones, L. E. Seager and M. R. J. Elsegood, Synlett, 2011, 211-214; (d) R. C. F. Jones and T. A. Pillainayagam, Synlett, 2004, 15, 2815-2817; (e) R. C. F. Jones, J. P. Bullous, C. C. M. Law and M. R. J. Elsegood, Chem. Commun., 2014, 50, 1588-1590; $(f)$ M. Falorni, G. Giacomelli and E. Spanu, Tetrahedron Lett., 1998, 39, 9241-9244; (g) M. Falorni, G. Giacomelli and A. M. Spanedda, Tetrahedron: Asymmetry, 1998, 9, 30393046; (h) L. De Luca, G. Giacomelli and A. Riu, J. Org. Chem., 2001, 66, 6823-6825.

14 D. C. Schmitt, L. Lam and J. S. Johnson, Org. Lett., 2011, 13, 5136-5139.

15 (a) Q.-f. Jia, P. M. S. Benjamin, J. Huang, Z. Du, X. Zheng, K. Zhang, A. H. Conney and J. Wang, Synlett, 2013, 79-84; (b) S. Zhu, S. Shi and S. W. Gerritz, Tetrahedron Lett., 2011, 52, 4001-4004.

16 C. C. Lee, R. J. Fitzmaurice and S. Caddick, Org. Biomol. Chem., 2009, 7, 4349-4351.

17 H. Kawai, Y. Sugita, E. Tokunaga and N. Shibata, Eur. J. Org. Chem., 2012, 1295-1298.

18 (a) S. Dadiboyena, J. Xu and A. T. Hamme II, Tetrahedron Lett., 2007, 48, 1295-1298; (b) J. Xu and A. T. Hamme II, Synlett, 2008, 919-923.

19 M. A. Schmidt, K. Katipally, A. Ramirez, O. Soltani, X. Hou, H. Zhang, B.-C. Chen, X. Qian and R. P. Deshpande, Tetrahedron Lett., 2012, 53, 3994-3997.

20 (a) A. O. Abdelhamid, A. A. Fahmi and K. N. M. Halim, Synth. Commun., 2013, 43, 1101-1126; (b) M. R. Shaaban, T. M. A. Eldebss, A. F. Darweesh and A. M. Farag, J. Heterocycl. Chem., 2008, 45, 1739-1744.

21 (a) A. Padwa and W. H. Pearson, Synthetic Applications of 1,3Dipolar Cycloaddition Chemistry toward Heterocycles and Natural Products, John Wiley \& Sons, Ltd, 2002; (b) R. Huisgen, Angew. Chem., Int. Ed. Engl., 1963, 2, 633-645; (c) L. N. Sobenina, D. N. Tomilin, M. D. Gotsko,
I. A. Ushakov, A. I. Mikhaleva and B. A. Trofimov, Tetrahedron, 2014, 70, 5168-5174.

22 (a) C. Bryant, I. D. Kerr, M. Debnath, K. K. H. Ang, J. Ratnam, R. S. Ferreira, P. Jaishankar, D. M. Zhao, M. R. Arkin, J. H. McKerrow, L. S. Brinen and A. R. Renslo, Bioorg. Med. Chem. Lett., 2009, 19(21), 6218-6221; (b) P. Jones, M. E. Difrancesco, A. Petrocchi, C. L. Carroll, J. Marszalek, B. Czako, R. Johnson, J. Theroff, US Pat. US2015252058 (A1), Feb 27, 2014.

23 L. Han, B. Zhang, M. Zhu and J. Yan, Tetrahedron Lett., 2014, 55, 2308-2311.

24 (a) T. Pasinszki, B. Hajgató, B. Havasi and N. P. C. Westwood, Phys. Chem. Chem. Phys., 2009, 11, 5263-5272; (b) G. Romeo and U. Chiacchio, in Modern Heterocyclic Chemistry, ed. J. Alvarez-Builla, J. J. J. Vaquero and J. Barluenga, Wiley-VCH Verlag \& Co., Weinheim, Germany, 2011, pp. 1047-1252.

25 B. Guillaume, K. M. Fiona, B. Renaud, L. Clemens, Q. Laura, T. Stephan, US Pat. US2014045890 (A1), Feb 13, 2014.

26 D. N. Reddy, R. Thirupathi, S. Tumminakatti and E. N. Prabhakaran, Tetrahedron Lett., 2012, 53, 4413-4417.

27 (a) S. P. Arneric, J. P. Sullivan, C. A. Briggs, D. DonnellyRoberts, D. J. Anderson, J. L. Raszkiewicz, M. Hughes, E. D. Cadman, P. Adams, D. S. Garvey, J. Wasicak and M. Williams, J. Pharmacol. Exp. Ther., 1994, 270, 310-318; (b) D. S. Garvey, J. T. Wasicak, R. L. Elliott, S. Lebold, A.-M Hettinger, G. M. Carrera, N.-H. Lin, Y. He, M. W. Holladay, D. J. Anderson, E. D. Cadman, J. L. Raszkiewicz, J. P. Sullivan and S. P. Arneric, J. Med. Chem., 1994, 37, 4455-4463.

28 (a) A. Plant, F. Stieber, J. Scherkenbeck, P. Lösel and H. Dyker, Org. Lett., 2001, 3, 3427-3430; (b) I. V. Komarov, A. O. Grigorenko, A. V. Turov and V. P. Khilya, Russ. Chem. Rev., 2004, 73, 785-810; (c) S. Pellegrino, A. Contini, M. L. Gelmi, L. Lo Presti, R. Soave and E. Erba, J. Org. Chem., 2014, 79, 3094-3102.

29 In particular, it was been recently demonstrated that terminal 2-oxasole-group is prone to induce $\beta$ conformation of the residue: (a) D. Siodłak, M. Staś, M. A. Broda, M. Bujak and T. Lis, J. Phys. Chem. B, 2014, 118, 2340-2350. 4,5-Thiasole-based building blocks with $(R)$-chirality have been used to promote $\beta$-turn structures in gramicidin $(S)$-analogues to construct peptidomimetics with reduced hemolytic activity: (b) B. Legrand, L. Mathieu, A. Lebrun, S. Andriamanarivo, V. Lisowski, N. Masurier, S. Zirah, Y. K. Kang, J. Martinez and L. T. Maillard, Chem.Eur. J., 2014, 20, 6713-6720.

30 R. A. Hughes and C. J. Moody, Angew. Chem., Int. Ed., 2007, 46, 7930-7954.

31 P. G. Arnison, M. J. Bibb, G. Bierbaum, A. A. Bowers, T. S. Bugni, G. Bulaj, J. A. Camarero, D. J. Campopiano, G. L. Challis, J. Clardy, P. D. Cotter, D. J. Craik, M. Dawson, E. Dittmann, S. Donadio, P. C. Dorrestein, K.-D. Entian, M. A. Fischbach, J. S. Garavelli, U. Göransson, C. W. Gruber, D. H. Haft, T. K. Hemscheidt, C. Hertweck, C. Hill, A. R. Horswill, M. Jaspars, W. L. Kelly, J. P. Klinman, O. P. Kuipers, A. J. Link, W. Liu, M. A. Marahiel, D. A. Mitchell, G. N. Moll, B. S. Moore, 
R. Müller, S. K. Nair, I. F. Nes, G. E. Norris, B. M. Olivera, H. Onaka, M. L. Patchett, J. Piel, M. J. T. Reaney, S. Rebuffat, R. P. Ross, H.-G. Sahl, E. W. Schmidt, M. E. Selsted, K. Severinov, B. Shen, K. Sivonen, L. Smith, T. Stein, R. D. Süssmuth, J. R. Tagg, G.-L. Tang, A. W. Truman, J. C. Vederas, C. T. Walsh, J. D. Walton, S. C. Wenzel, J. M. Willey and W. A. van der Donk, Nat. Prod. Rep., 2013, 30, 108-160.

32 K. L. Dunbar and D. A. Mitchell, J. Am. Chem. Soc., 2013, 135, 8692-8701.

33 R. S. Roy, A. M. Gehring, J. C. Milne, P. J. Belshaw and C. T. Walsh, Nat. Prod. Rep., 1999, 16, 249-263.

34 E. M. Nolan and C. T. Walsh, ChemBioChem, 2009, 10, 34-53. 35 V. S. C. Yeh, Tetrahedron, 2004, 60, 11995-12042.

36 For instance see total synthesis of plantazolicin A: (a) S. Banala, P. Ensle and R. D. Süssmuth, Angew. Chem., Int. Ed., 2013, 52, 9518-9523; microcin B17: (b)
R. E. Thompson, F. Collin, A. Maxwell, K. A. Joliffe and R. J. Payne, Org. Biomol. Chem., 2014, 12, 1570-1578; sansavamide A: (c) M. R. Davis, E. K. Singh, H. Wahyudi, L. D. Alexander, J. B. Kunicki, L. A. Nazarova, K. A. Fairweather, A. M. Giltrap, K. A. Jolliffe and S. R. McAlpine, Tetrahedron, 2012, 68, 1029-1051; (R)telomestatin: (d) T. Doi, M. Yoshida, K. Shin-ya and T. Takahashi, Org. Lett., 2006, 8, 4165-4167; or dendroamine A: (e) Z. Xia and C. D. Smith, J. Org. Chem., 2001, 66, 3459-3466.

37 Curiously, epimerization of the AlaIso residue in Ac-LeuAlaIso-Val- $\mathrm{NH}_{2}$ (but not in Ac-Leu-Val-AlaIso- $\mathrm{NH}_{2}$ ) would potentially lead to a $\beta$-turn structure rather than semiextended $\beta$. This may be the driving force for the partial epimerization observed experimentally.

38 G. Chennakrishnareddy, B. Vasantha, N. Narendra and V. V. Sureshbabu, Int. J. Pept. Res. Ther., 2011, 17, 185-191. 